IZA DP No. 6848

Do Chinese Employers Avoid Hiring Overqualified Workers? Evidence from an Internet Job Board

Kailing Shen

Peter Kuhn

September 2012 


\title{
Do Chinese Employers Avoid Hiring Overqualified Workers? Evidence from an Internet Job Board
}

\author{
Kailing Shen \\ WISE, Xiamen University \\ and IZA \\ Peter Kuhn \\ University of California, Santa Barbara, \\ NBER and IZA
}

\section{Discussion Paper No. 6848 \\ September 2012}

IZA

\author{
P.O. Box 7240 \\ 53072 Bonn \\ Germany
}

\author{
Phone: +49-228-3894-0 \\ Fax: +49-228-3894-180 \\ E-mail: iza@iza.org
}

\begin{abstract}
Any opinions expressed here are those of the author(s) and not those of IZA. Research published in this series may include views on policy, but the institute itself takes no institutional policy positions.

The Institute for the Study of Labor (IZA) in Bonn is a local and virtual international research center and a place of communication between science, politics and business. IZA is an independent nonprofit organization supported by Deutsche Post Foundation. The center is associated with the University of Bonn and offers a stimulating research environment through its international network, workshops and conferences, data service, project support, research visits and doctoral program. IZA engages in (i) original and internationally competitive research in all fields of labor economics, (ii) development of policy concepts, and (iii) dissemination of research results and concepts to the interested public.
\end{abstract}

IZA Discussion Papers often represent preliminary work and are circulated to encourage discussion. Citation of such a paper should account for its provisional character. A revised version may be available directly from the author. 
IZA Discussion Paper No. 6848

September 2012

\section{ABSTRACT}

\section{Do Chinese Employers Avoid Hiring Overqualified Workers? Evidence from an Internet Job Board}

Can having more education than a job requires reduce one's chances of being offered the job? We study this question in a sample of applications to jobs that are posted on an urban Chinese website. We find that being overqualified in this way does not reduce the success rates of university-educated jobseekers applying to college-level jobs, but that it does hurt college-educated workers' chances when applying to jobs requiring technical school, which involves three fewer years of education than college. Our results highlight a difficult situation faced by the recent large cohort of college-educated Chinese workers: They seem to fare poorly in the competition for jobs, both when pitted against more-educated university graduates, and when pitted against less-educated technical school graduates.

JEL Classification: J64, J24

Keywords: $\quad$ overqualification, job search, internet, China

Corresponding author:

Peter Kuhn

Department of Economics

University of California, Santa Barbara

2127 North Hall

Santa Barbara, CA 93106-9210

USA

E-mail: pjkuhn@econ.ucsb.edu 


\section{Introduction}

Between 2002 and 2010 the number of college and university graduates entering China's labor market increased more than five-fold, from about 1 million to over 5 million new graduates per year. ${ }^{1}$ While China's demand for highly educated workers has also been increasing, concern has been widely expressed regarding how this massive influx of young, highly educated workers will be absorbed by China's labor market. The prospect of a large number of under- or unemployed young college graduates worries many observers.

While China's recent expansion of higher education may be unique in its magnitude, the notion that workers may experience difficulties getting hired for a job because they have more education than the job requires has a long history. Indeed, the broader problem of overqualification for the available jobs has been a widely expressed concern among older jobseekers in the U.S.'s recent "great recession". ${ }^{2}$ In this paper, we use internet job board micro data to examine the overeducation hypothesis: are there conditions under which having too much education can harm a jobseeker's prospects of being hired, and do these conditions apply to recent university graduates in China?

Our study contributes to three literatures. First, our study of the micro-level competition between applicants for the same jobs adds to our understanding of the mechanisms via which education expansion policies such as China's affect the overall labor market. Second, our study provides new information on the substitutability between workers with different levels of education, which is a key parameter for a number of canonical questions in labor economics, including the effects of immigration and skill upgrading on wage structures. ${ }^{3}$ Finally, we contribute to a small economic literature on overqualification. While this literature has studied a number of consequences of overqualification, we are not aware of any existing studies of the effects of overqualification on the probability a worker will receive a job offer.

Our data is from www.xmrc.com.cn, the official internet job board sponsored by the department of human resources of Xiamen, one of the major cities in China's coastal region. For the period from May to October 2010, we have detailed information on all the jobs that were posted and all the applications workers made to those jobs. Only about eight percent of the applicants in our sample are contacted by the firm after submitting their application; we use receiving such a contact as our measure of jobseeking success. In our main analysis, we focus on workers with just two different levels of education: college and university; these are the two main forms of postsecondary education in China and require three versus four years to complete, respectively. Our results show, first of all, that university graduates have an advantage over college graduates when both types of workers are competing for the same job. This is true both when the job ad requests university education (in which case university graduates have about a two percentage point advantage), and when the ad requests only college education (in which case university graduates have about a one percentage point advantage over college-educated applicants). Second, we

\footnotetext{
${ }^{1}$ Statistics are from China Education Statistical Yearbook. See Section 2 for a more detailed discussion of recent trends in Chinese higher education.

${ }^{2}$ See for example Rossheim (2012).

${ }^{3}$ See for example Card (2009).
} 
ask whether, ceteris paribus, university-educated candidates are more likely to be contacted by employers when applying to college-level jobs (for which they are overqualified) or when applying to jobs that match their educational credentials. Perhaps surprisingly, in contrast to the overeducation hypothesis we find that university-educated workers actually receive more employer contacts when applying for collegelevel than university-level jobs. Finally, we show that the above results are driven mostly by Chineseowned firms (both private-sector firms and state-owned enterprises). Foreign-owned firms behave differently, in a manner that is more consistent with their job ads. These firms seem to prefer collegeeducated applicants to university-educated applicants when their ad requests a college-educated worker.

Our paper also studies the overeducation hypothesis at a lower tier of the Chinese labor market: the competition between college graduates and technical school graduates, who have three fewer years of education than college graduates. Here our results are very different: College graduates do, indeed, fare quite poorly when they apply to tech-school jobs. We speculate that this may result from the greater education mismatch between these two types of education, including the fact that college grads may lack specific vocational skills taught in technical schools. Together, our results suggest that overqualification can reduce the chances of receiving a job offer, but that the effects can vary across levels and types of education. Also, China's recent college graduates appear to face a relatively difficult situation, sandwiched between two groups with whom they do not seem to compete well.

\section{The development of higher education in China}

To put our results on educational expansion and over-education in context, this Section provides a brief review of the recent evolution of China's system of higher education. The modern school system in China was established in the early $20^{\text {th }}$ century. Until 1949, China's higher education system mainly followed the American model. After 1949, the central government of the People's Republic of China restructured the higher education system according to the Soviet model. As a result, it became part of the centrally planned economy with full public financial support and all graduates were assigned jobs according to the government plan. It "became departmentalized, segmented and overspecialized; teaching was separated from research" (Bai, 2006). In 1958, China made an attempt to expand its higher education which eventually failed together with the Great Leap Forward. After the end of the Cultural Revolution (1966-1976), China gradually restored its system of higher education and started to reform the system as part of the overall move to a market-oriented socialist economy.

By the end of 1980s, China's higher education system suffered from both financial difficulties due to fast expansion and rapidly rising costs, as well as inefficient use of recourses. Universities were either administrated by the Ministry of Education, or by some specialized national ministries, state-owned enterprises, national associations or local education bureaus, local ministries or state-owned enterprises. The average size of higher education institutions was less than 2000 students in 1989 and the average student/teacher ratio was as low as 5.3:1 in 1988 (Wang 2001).

As a result of higher education reform in the 1990s and especially the expansion of 1999, smaller colleges and universities were merged into bigger ones; local governments and universities themselves 
started to get more funding as well as administration responsibilities; and students started to pay tuition, which for many families in the less-developed regions costs more than their annual income. Importantly for the purposes of this paper, university students now had to search for jobs upon graduation whereas before the reform, university graduates were assigned jobs in the government or the state owned enterprises. According to Kang (2000), the official justifications for the 1999 enrollment expansion policy were, first, the expected increase in demand for skilled labor in the face of globalization; second, the need to stimulate domestic demand and to alleviate the rising urban unemployment problem after the 1997 Asian crisis; and finally, to achieve "mass higher education".

Based on the number of new graduates created, the 1999 enrollment expansion was a stunning success. As Figure 1 shows, the total new admissions of college and university together increased more than five-fold by 2009. Figure 2 shows that between 1986 and 2004 the number of university and college graduates were of similar magnitude and increased at similar speed. Starting from 2005, however, the number of college graduates increased faster than university graduates. Starting at the same time, the number of technical school graduates also increased dramatically after some previous stagnation.

Less clear, however, is whether the new graduates have the skills needed for China's "new" labor market, or whether they are getting the types of jobs they expected to be qualified for. For example, Figure 3, which shows time trends in official vacancy statistics, suggests that the demand for college and university graduates has not increased as much as the supply. ${ }^{4}$ Public discussions also seem to suggest an emerging shortage of high school and technical school graduates. College and university students, who now pay much higher tuition than before, might reasonably demand to see a corresponding return for their investment, but this is not always the case: many universities are still learning to adapt their curriculum to market demand with a limited supply of qualified faculty, so graduates' skills may not match the market's needs. It can also be difficult for new graduates to take good jobs in regions other than their home region due to various administrative restrictions, including the hukou system. Overall, a number of observers have argued that recent university graduates are finding it difficult to get the "good jobs" they have been expecting (Lai 2001, Zeng 2004, Yao 2009, and Wang and Zeng 2009).

\section{The literature on overqualification}

In general, overqualification refers to a situation where a worker has more education, or a higher level of some other skill or credential, than is required to perform a job. Measuring overqualification therefore requires some indicator of a job's skill requirements, which can be either taken from third-party studies, such as in the U.S. Dictionary of Occupational Titles, or from employers' statements about what

\footnotetext{
${ }^{4}$ High school, technical school, college and university are the four main education categories in China. Both high school and technical school require 12 years of education, but technical school provides specialized training in the last 3 years for students most of whom will enter the labor market upon graduation. High school graduates usually will take college entrance exams for higher education upon graduation. Here, we use "college" to refer to 3-year higher education and "university" to refer to 4-year higher education. The labor market generally will consider these two distinct levels of education in China as will become clear from our empirical analysis. Technical schools in China actually can refer to three different types of secondary vocational schools, 1) specialized secondary schools (mostly theoretical courses with some practical training), 2) technical schools (mostly practical training with some theoretical courses) and 3) secondary vocational schools (mostly regular senior middle school courses with some vocational courses). We do not distinguish these three types of secondary vocational schools in our analysis due to data limitations and refer to these as technical schools for ease of understanding.
} 
is required or expected. In this paper we follow most of the literature by taking the latter approach: we will refer to a worker as being overeducated for a particular job if he/she has more education than the employer requests in the job ad on XMRC.com.

Interestingly, none of the existing research on overqualification we are aware of studies whether being overqualified can harm a worker's chances of being offered a job. Instead, --perhaps because data such as ours on the job application and worker recruitment process is so rare-existing literature tends to focus on measuring (a) what fraction of workers, and which workers are employed in jobs for which they are overqualified, and (b) what happens to those workers (for example, are they more likely to quit their current job?). Overviews of this literature can be found in Borghans and Grip (2000) and Hartog (2000).

More recently, Frenette (2004) examined the incidence, persistence and economic returns to overqualification among Canadian post-secondary graduates using panel data. He found that master's graduates are far more likely to be overqualified for their current job than others. McGuinness and Sloane (2011) examined both overqualification and over-skilling and suggested that overqualified workers might choose their lower-wage jobs for other positive job attributes. In his study of German data, Buchel (2002) finds that overeducated workers are healthier, more strongly work- and career-minded, more likely to participate in training, and more stable in their jobs, all of which would justify employers' willingness to hire overeducated workers. Green and Zhu (2010) suggest that a large increase in the supply of university graduates can lead to increased dispersion of the returns to graduate education through increased overqualification. In addition to the above, Buchel and Battu (2003) examined the relationship between labor market size and gender difference in overqualification using German data; Hersch (1991, 1995) suggests that firms might want to hire overqualified workers to save training costs; and Renes and Ridder (1995) suggest that firms might use higher qualification requirements to discourage women from applying to a job.

There are also some empirical studies of overeducation using Chinese data. Using data from the Urban Household Survey, Huang, Lu and Fan (2010) estimated that overeducated individuals experience a $4.8 \%$ wage penalty relative to persons with the same education in jobs that match their qualifications. ${ }^{5}$ $\mathrm{Li}$, Chen and Liu (2009) using survey data on university graduates find that individuals who are more flexible in job location and more interested in their major are less likely to have education-mismatched jobs. Wu (2007) also shows that the return to education is lower for overeducated workers than 'education-matched' workers.

In short, while a number of authors have studied overqualification in Chinese and other labor markets, existing research seems to focus only on determining how many and which workers are employed in jobs they are overqualified for, or on measuring the consequences of being in such a job on outcomes such as workers' happiness and job mobility. To our knowledge, no one has studied whether firms 'shy away' from hiring workers who have more educational qualifications than are needed for a job,

\footnotetext{
${ }^{5}$ The overeducation measure used in their work is derived by comparing individual actual earning with the average earnings of one of eight general occupation groups.
} 
despite the fact that this is often cited by workers as a significant impediment to their job search. This is the question we address here.

\section{Data}

The city where we collected our data, Xiamen, is a subtropical coastal city in southern China. It is one of the five economic zones established immediately after China's 1979 economic reforms; thus it is highly modernized and integrated into the world economy relative to other Chinese cities. The economy of Xiamen is based mainly on electronics, machinery and chemical engineering; Xiamen contains one of Dell Computer's five global production and service centers. Table 1 provides some statistics that compare Xiamen to other Chinese cities as of 2010. While considerably smaller than Beijing and Shanghai, Table 1 shows that Xiamen's income levels are similar to those cities, with annual GDP per capita at 58,337, 75,943 and 76,074 RMB for Xiamen, Beijing and Shanghai respectively. ${ }^{6}$ Xiamen's per capita GDP is similar to the mean of the 15 sub-provincial cities in China, but much higher than the 268 Di-level cities ${ }^{7}$. Like Beijing and Shanghai, Xiamen is also a city with many internal migrants: only about half of the population of Xiamen has a permanent local residence permit (hukou); this is actually lower than the share in Beijing and Shanghai. A little more than half of the population of Xiamen, whether local hukou owner or not, is employed, similar to Beijing and much higher than Shanghai and sub-provincial and Di-level cities on average. Finally, about half of Xiamen's employed population works in the private sector, which is very typical of Chinese cities with the exception of Beijing.

The source of our data is internal microdata from www.xmrc.com.cn, the official internet job board sponsored by the department of human resources of the city of Xiamen. More specifically, our data are based on all the new job postings for the period from May $1^{\text {st }}$ to October $31^{\text {st }} 2010$ on this website. We collected detailed information on all these job ads, as well as the characteristics of all the firms who posted the ads and all the workers who applied to them. Thus, for every ad that was posted during this period, we know not only the characteristics of the ad, but the characteristics of each worker who responded to that ad via the XMRC website. We also know which applicants were ultimately contacted by the firm's HR department through the site, and we use this as our measure of workers' success. ${ }^{8}$

\footnotetext{
${ }_{7}^{6}$ In December 2010 one US dollar bought 6.65 RMB.

${ }^{7}$ According to the 2011 China City Statistical Yearbook, the 657 cities in China are grouped into 4 categories from an administrative perspective: 1) 4 municipalities directly under the jurisdiction of the central government (Beijing, Shanghai, Tianjing and Chongqing); 2 ) 15 sub-provincial cities; 3) 268 Di-level cities, and 4) 370 Xian-level cities. Xiamen is a sub-provincial city. Sub-provincial cities have more independency in economic and social development management than Di- and Xian-level cities. The leaders of sub-provincial cities are also of higher administrative rank. Five cities out of these 15 cities, including Xiamen, also have independent economic planning in the national system and the expense and revenue of these 5 cities are shared with the central government directly rather than the relevant provinces. The Di-level cities are of a higher administrative rank than Xian-level cities and usually contain several districts and are directly administered by the provincial government. Most Xian-level cities are administered by Di-level cities on behalf of the provincial government.

${ }^{8}$ Note that although we select job ads that have first applications no later than October 31 2010, we see all applications and contacts that occurred till January 13 2011, which is 74 days after the latest job ads appeared online and when lunar New Year of China was about to start and most labor market activities are stopped. Moreover, most applications on the website either result in contacts very quickly or not at all. Of all applications resulted in contacts, $87.39 \%$ happened within the first 7 days after the application, and $93.19 \%$ happened within 14 days. Therefore, we believe it is not likely that differences in the time it takes to fill college versus university applications induce differential selection into our sample.
} 
Because our dependent variable is the receipt of an employer contact, our analysis shares a key limitation of all call-back-based studies (e.g. Bertrand and Mullainathan 2004): we do not see which workers were actually offered jobs or were ultimately hired. Thus, if candidates are selected from the list of contacts in a very different way than they are selected for contacts, our results will not be representative of success in getting hired. Still, the fact that the vast majority of the applicants are eliminated in the selection-for-contact stage (only about 7 percent receive employer contacts—see Table 6) suggests that the patterns identified in our data are also the main determinant of ultimately getting the job.

Our main statistical analysis in this paper uses a sample of 93,988 applications, submitted by 39,732 workers to 1,219 job ads posted by 760 distinct firms. This sample was extracted from the universe of applications that were made during our sampling period according to the following criteria: First, we include only applications made by workers with either college or university education, which were directed to job ads that requested either college or university education. Second, to focus on the transition from higher education to work, we restricted our applicants' ages to be between 18 and 35 and the jobs' experience requirement to be no more than 3 years. ${ }^{9}$ Finally, note that firms can contact workers they are potentially interested in hiring through a number of channels (such as telephone) other than through the XMRC site itself; indeed for a significant number of ads posted on XMRC we observe that no resumes at all are contacted by the firm during the observation period. Since our main interest is in which of the applicants to a job are selected by the firm to be contacted for further interviews (and not how the applicant was contacted), we include in our sample only those job ads that resulted in at least one worker being contacted by the firm via the XMRC website. ${ }^{10}$

Table 2 presents the sample composition with regard to job applicants. The applicants are grouped into four categories according to their education as well as the education requirement of the jobs to which they applied. As the sample sizes show, a large majority $(13521 /(13521+3578))=79 \%$ of university graduates applied to at least one college-level job, while only $3795 /(18838+3795)=17 \%$ of college graduates applied to any university jobs. So it appears that recent university graduates do not hesitate to apply for jobs they are overqualified for, but college graduates mostly avoid applying for jobs they are underqualified for. Unsurprisingly, those university-educated workers who also apply to college jobs tend to send out more applications: the more applications one sends, the greater are the chances one of them will go to an education-mismatched job. A similar pattern also applies to college workers who also apply to university jobs. Finally, Table 2 shows, as we would expect, that the likelihood of being contacted by an employer increases with the number of applications a worker sends out.

\footnotetext{
${ }^{9}$ We also drop a small number of jobs offering a salary of more than 12,500 RMB per month and a small number of applicants with current salaries above that level. Applicants who do not have Chinese nationality are also excluded from the sample.

${ }^{10}$ A consequence of this sampling strategy is that ads which first appear on the site close to the end of our sampling period (October 312010$)$ may be be less likely to appear in our sample because these ads are followed for 74 days, whereas our earliest job ads which first appear on May $1^{\text {st }} 2010$ could potentially be followed for 257 days. Since most ads are responded to quickly or not at all, this is unlikely to induce much length-biased sampling. Still, to ensure that any remaining bias does not account for our results, we created a second sample that consisted only of ads that resulted in a contact within 60 days of being posted; since we can follow all ads for at least 72 days this allows us to apply the same selection criterion regardless of when the ad was first posted. The results were very similar and are available from the authors on request.
} 
Table 3 presents the sample composition with regard to job ads. Like workers' applications, the job ads are grouped into 4 categories according to their education requirement as well as the education qualifications of job applications received. On average, each job ad in our database received 77 applications. As the table shows, almost all job ads receive at least one application with mismatched educational credentials; indeed the small portion of job ads that only received applications from individuals with matched education qualification also only received relatively few (under 40) applications. Table 3 also shows that as the number of applications received rises, the chances that any single application is contacted fall. This illustrates the within-firm competition among applicants that plays a central role in many directed search models (e.g. Lang, Manove and Dickens, 2005).

Additional details on our sample of applicants are provided in Table 4. It shows that, compared with college graduates, university graduate applicants are more likely to be single, to be new graduates, and have less work experience. Compared to university graduates who only applied to university-level jobs, university graduates who applied to jobs for which they are overeducated are more likely to be female, married, and have more experience. This gender pattern is consistent with women being less (over)confident in their application decisions (Niederle and Vesterlund 2007), or perhaps rationally expecting to encounter discrimination in the hiring process. Table 5 provides similar information on job characteristics. It shows that there are many more job ads requiring college education than requiring university education. Relative to college jobs, university jobs are less likely to have a gender requirement, and more likely to be in firms with more than 300 employees. ${ }^{11}$ The distribution of firm ownership is very similar across college- and university-level jobs, with about 70 percent of the jobs in domestic, private sector firms.

Finally, Table 6 shows the mean of our main dependent variable (whether an application received a 'call-back' via the website) for our entire sample of applications. Applications are broken down into four types based on the worker's education level and the job's education requirement, thus for example column 2 (CU) refers to applications made by college-educated workers to university-level jobs. It shows that university-educated workers are more likely to receive call-backs regardless of which type of job they apply to, that college-educated workers' call-back rate drops from 7.72 to 6.07 percent when they apply to university-level jobs, and that university-educated workers' call-back rate rises from 8.08 to 8.70 percent when they apply to college-level jobs. In the following section, we show that these simple comparisons survive highly detailed controls for both job and worker characteristics, and the match between them.

\section{Econometric specification}

We use linear probability regressions on our sample of applications to study the impacts of education (mis)match on firms' hiring behavior. The general form of the regression equation can be written as follows:

\footnotetext{
${ }^{11}$ See Kuhn and Shen (2012) for an analysis of Chinese firms' decisions to gender-target their job ads.
} 
$Y_{i j}=\alpha_{0}+\alpha_{1}\left(U C_{i j}+U U_{i j}+C U_{i j}\right)+\alpha_{2}\left(U U_{i j}+C U_{i j}\right)+\alpha_{3} C U_{i j}+\beta M a t c h_{i j}+\gamma X_{i}+\lambda Z_{j}+\delta P o o l_{j}+\mu_{i j}$

Here, the dependent variable $Y_{i j}$ equals one if the application (by worker $i$ to job ad $j$ ) resulted in the worker being contacted by the firm's HR department. As noted, our main results are based on a sample of applications containing only two types of workers --college or university-educated-and only two types of job ads: those requesting college education, or university education. Thus we have four types of applications, classified by the applicant's and job's type; these define four indicator variables where, for example, $U C_{i j}$ equals one for university-educated workers applying to college-level jobs and zero in all other cases. As specified, our regression equation directly estimates three parameters of interest. In particular, $\alpha_{1}$ measures the difference in contact rates between the $U C$ category and the omitted (CC) category, in other words $\alpha_{1}$ measures university-educated workers' advantage over collegeeducated workers when both are competing for college-level jobs. ${ }^{12}$ By the same logic, $\alpha_{3}$ measures college-educated workers' advantage over university-educated workers when both are competing for university-level jobs. Finally, $\alpha_{2}$ conducts a different type of comparison that applies specifically to university-educated workers, and is probably most relevant to the overeducation hypothesis: $\alpha_{2}$ measures the gain (in contact rates) experienced by a university-educated worker from applying to an educationappropriate job (UU) instead of a job for which the worker is overqualified (UC).

In most of our regression specifications, we use the vector Match $_{i j}$ to control for the match between the applicant's qualifications and the job's requirements on dimensions other than education. Specifically, Match $_{i j}$ includes dummies for whether the applicant is younger than required, older than required, less experienced than required, more experienced than required, of different gender than required, and of different "new graduate" status than required. ${ }^{13}$

The vector $X_{i}$ contains applicant-specific variables. In particular, $X_{i}$ includes dummies for whether the applicant is female, has ever been married, has local hukou (household registration), is (literally) myopic, and is a new graduate. It also contains a set of age effects (dummies for 23-25, 26-30 and 31-35, with 18-22 as the omitted category) and experience effects (1 year, 2 years, and 3 years or above, with zero as the omitted category). The vector $Z_{j}$ contains job- and firm-specific variables. In particular, we use dummies for whether the ad requests that the applicant be a new graduate, be male, or be female, as well as a set of dummies for the ad's experience requirement ( 1 year, 2 years and 3 years, with zero as omitted category) and dummies for 7 major occupations. The firm-specific variables include dummies for firm size (1-10, 11-50, 51-300 and 301 or more workers) and dummies for firms' ownership type. Firm ownership categories are domestic privately-held firms, foreign firms (joint ventures, representative offices and foreign direct investment firms), and firms owned by Taiwan/Hong

\footnotetext{
${ }^{12}$ To see this, note that when $U C=1, Y=\alpha_{0}+\alpha_{1}$ and when $C C=1, Y=\alpha_{0}$.

${ }^{13}$ Some ads explicitly request that the applicant be a new graduate.
} 
Kong/Macau investors, with an omitted category of domestic non-private firms, which includes stateowned enterprises (SOEs), stock market listed firms, not for profit organizations, etc.

Finally, in some specifications, we also include a set of variables measuring the size and composition of the pool of applications that are competing for the same job with the current application, Pool $_{j}$. The key variable here is the total number of applications received for the job. To allow competing applications from mismatched workers to have different effects from matched workers' applications, we also include two additional variables. One of these equals the number of university-educated applicants if the job requires college education (and zero otherwise). It captures the effect of replacing one application that matches the job's requirements (college) with a non-matching (university) applicant. The remaining variable equals the number of college-educated applicants if the job requires university education (and zero otherwise); it is interpreted analogously.

Despite our rich set of covariates, it of course remains possible that our samples of universityversus college-educated workers differs in unobservable ways that affects their employment probability. One possibility, for example, is that workers who choose to look for work online are negatively selected (Kuhn and Skuterud 2004), and that this selection is more pronounced for, say, university- versus collegeeducated workers. While we cannot think of any reasons why selection into Internet search differs for these two groups, we caution that such differential selection could affect our results. Accordingly, our results should be interpreted as applying to employers' differential treatment of university- versus collegeeducated workers who post their resumes on XMRC. While selection onto this site might differ by worker type making it difficult to generalize to the entire labor market, our results clearly show that employers do not 'shy away' from university-educated workers when they apply to jobs they are overqualified for on this site.

\section{Results: University versus College Graduates}

Table 7 presents our main results for university versus college graduates in two panels. All specifications estimate the impact of the three key indicators of education (mis)match, and Panel B mimics Panel A but with the Pool $_{j}$ variables added. Moving across the Table from column 1 to 4, we add matching variables (on characteristics other than education), applicant's variables, and job variables sequentially to the regression. According to the estimate of $\alpha_{1}$ in row 1, university-educated workers applying to college-level jobs are more likely to be contacted by the employer than college-educated workers applying for the same job. Based on the most saturated specification in column 4, universityeducated workers' advantage in the competition for college-level jobs is 0.86 percentage points. This is a sizable effect since, according to Table 7; the mean contact rate for college-educated workers applying to education-appropriate jobs is 7.72 percent. In other words, university-educated workers have about an $(.86 / 7.72)=11$ percent advantage over college-educated workers in the competition for college-level jobs. Perhaps less surprisingly, our estimates of $\alpha_{3}$ show that university-educated workers also have an 
advantage over college-educated workers in the competition for university-level jobs. At between 1.3 and 2.0 percentage points, this advantage is larger than their advantage in the competition for lower-level jobs.

Estimates of $\alpha_{2}$, which address the overeducation hypothesis most directly, show (perhaps surprisingly) that university-educated workers are less likely to be contacted by firms when they apply for education-matched jobs than for college-level jobs. Panel B of Table 7 shows that the above results for $\alpha_{1}$, $\alpha_{2}$, and $\alpha_{3}$ are robust to adding controls for the size and mix of the applicant pool a resume is competing with. The coefficients on the education-matching variables are essentially unchanged, suggesting that while these applicant pool effects certainly matter for hiring rates-- their effects are largely orthogonal to whether the current application is education-matched. ${ }^{14}$

In sum, Table 7 shows that (1) that firms certainly do consider education mismatched applications (the contact rate does not drop to zero when the applicant is mismatched on education); (2) in the competition for jobs requiring a given amount of education, Chinese employers tend to favor workers with more education, even when that education is more than the firm requested in its job ad; and (3) there is no support for the overeducation hypothesis as an explanation for why young university-educated workers have difficulty finding jobs: university-educated workers are more likely to be short-listed when they apply for jobs they are overqualified for than when they apply for education-appropriate jobs.

To learn more about the impacts of education mismatch on firms' hiring decisions, we interacted the 4 types of education (mis)match with other application characteristics one by one. Overall, the patterns found in Table 7 were very stable across subgroups with the following exceptions: First, the hiring advantage associated with overeducation is not present when the applicant is older than required, when the job requires new graduates, or when the job specifically requests male applicants. Second, the impacts of education mismatch are very different across firms of different ownership types. This is shown in Table 8, which replicates specification (4) of Table 7 with interactions between firm type and the education matching variables. Unsurprisingly, the results for private domestic firms in column 3 of Table 8 mirror those in Table 7, since these firms constitute a large majority of our sample. Other types of firms, however, behave quite differently; probably the most salient difference is that our estimate of $\alpha_{1}$ is negative for foreign-owned firms. In this sense, foreign-owned firms behave in a way that is more consistent with their stated education requirement in job ads: university-educated workers actually do worse than college-educated workers in the competition for college-level jobs. The other large difference across firm types in Table 8 is the large positive value of $\alpha_{1}$ in "other" firm ownership category, which includes SOEs. While this seems to indicate that SOEs have a strong preference for university-educated workers even when they advertise for college-educated workers, we caution that this is a small category and contains employer types other than SOEs.

\footnotetext{
${ }^{14}$ In all cases, the applicant pool variables show that a larger pool of competing applications reduces one's chances of being contacted by the employer; these effects are highly statistically significant. For both job types, the impacts of additional applications from educationmismatched candidates are very different across firms of different ownership types.
} 
Why do firms with different ownership behave so differently in their recruiting patterns in terms of education (mis)match? One possibility is that mismatch is more costly to non-local firms, perhaps because they face higher hiring costs. This would make it more difficult to replace an overeducated worker who stays for a short period, then moves on to a better job elsewhere. The same would apply if non-local firms engage in more training, including such activities as teaching a foreign corporate culture and language of business. Further research on the causes of these behavioral differences might shed interesting light on differences in explicit and implicit employment contracts between domestic Chinese and international firms.

\section{Results: College versus Technical School Graduates}

To see if our results on overqualification extend to other education levels, we duplicated the regressions in Tables 7 and 8 for a less-educated sample of jobs and workers. Specifically, we focused on firms' choices between college graduates and technical school graduates in a sample of jobs requiring one of these two education levels. Here, we might expect firms seeking tech school graduates to be more likely to avoid overqualified college-educated workers than in our main analysis, for two reasons. First, in contrast to university graduates who have one more year of education than college graduates, college graduates have three more years of education than tech school graduates. So in a sense college grads applying to tech school jobs are more overqualified than university grads applying to college-level jobs. Second, technical schools provide specific vocational preparation, which might make them better prepared for certain jobs than college grads. Essentially, college and technical school graduates may not be as substitutable as university and college graduates from the employer's perspective.

Regression results for the case of competition between technical- and high-school graduates are presented in Tables 9 and 10; the specifications for these Tables exactly mimic those of Tables 7 and 8. The results show, first of all, that in contrast to university graduates competing for college jobs, college grads $d o$ have a significant disadvantage in competing for tech-school jobs: all our estimates of $\alpha_{1}$ are negative and highly statistically significant. Specifically, college applicants to tech-school jobs are about 1.7 percentage points less likely to be contacted than tech-school applicants to those jobs. Perhaps even more surprisingly, our estimates of $\alpha_{3}$ indicate that tech school grads experience no disadvantage relative to college grads when applying to jobs requesting college education. Finally, our most direct test of the overeducation hypothesis $\left(\alpha_{2}\right)$ shows that college-educated workers gain a great deal from directing their

applications to jobs requesting a college education, relative to a lower level of education. In the specifications without applicant pool controls, these workers are estimated to experience a 1.5 percentage point drop in the probability of being contacted by the employer when they apply to tech school jobs. In the presence of application pool controls, this loss rises to about 3.0 percentage points, which is a reduction (relative to this group's mean contact rate) of about 40 percent. Thus, Chinese employers $d o$ avoid overqualified workers in this context, where the education gap is larger and the less-educated group might have specific vocational skills not possessed by the group with higher education. 
Does firms' treatment of overqualified college graduates vary with their ownership type, as it did for university graduates? Table 10 shows that firm ownership matters in this context as well. While the patterns for domestic, private-sector firms again mirror the aggregate results as expected, we now see large increases in the magnitude of $\alpha_{2}$ in foreign firms. College-educated workers applying to foreign firms seem to do much better when the job requests college school than tech school, with an estimated differential success rate of four or five percentage points. A similar pattern holds for Taiwan/Hong Kong/Macau-based firms. A possible explanation for this pattern, again, is higher recruitment and training costs among non-local firms: these firms might especially want to avoid hiring college-educated workers into jobs they are overqualified for if the costs of replacing those workers is high.

In sum, our analysis of job competition at lower skill levels reveals that college graduates face a significant disadvantage in competing for tech-school jobs, while technical-school graduates have no disadvantage in competing for college jobs. The contrast between these results and our results for the competition between university and college graduates illustrates the importance of considering the specific educational context in any analysis of over- or underqualification, not just the modern Chinese context.

\section{Conclusions}

This paper has used online job board micro data to study the relative performance of universityand college-educated workers in the competition for jobs in urban China. Our results show that university graduates have an advantage over college graduates, not only in the competition for university-level jobs, but also in the competition for college-level jobs. Further, university-educated workers are more likely to be contacted by employers when applying to jobs they are overqualified for than when applying to jobs that match their educational credentials. Together, these results contradict the 'overeducation hypothesis' which posits that having more education than a job demands can reduce a worker's chances of being offered the job if he or she applies for it. The one exception to this in the competition between university and college graduates is for foreign firms; these firms seem to avoid hiring overqualified workers, which may indicate that they face greater labor market frictions, whether in the form of hiring costs or firmspecific training levels.

We also conduct a parallel analysis of the competition between college- and technical-school graduates, finding that in this competition, college-educated workers $d o$ fare quite poorly when applying to jobs they are overqualified for. A possible explanation is the greater amount of mismatch between these two education levels: not only do college graduates have three more years of education than technical school graduates (in contrast to one year of mismatch between university and college graduates), but technical school grads may have specific vocational skills that college grads lack. Combined with our main analysis, these results highlight the difficult situation facing recent college graduates in China: they seem to fare poorly when competing against workers who are better-educated than they are, and when 
competing against the much-less-educated technical school graduates. In short, this middle group may bear the main burden of adjustment to China's recent massive expansion of higher education.

In addition to shedding some light on recent developments in the Chinese labor market, our results also contribute to a more general literature on the effects of overqualification. While a number of other authors have studied the prevalence and behavior of persons currently working in jobs they are overqualified for, to our knowledge no one has studied how overqualified workers 'stack up' relative to other candidates in the competition for jobs, especially using recruiting stage micro data. Our findings, that university-educated workers do well when applying for jobs they are overqualified for, but collegeeducated workers do not, suggest that the effects of overqualification may depend critically on the nature of a country's educational institutions and the types of skills that are taught in those institutions. 


\section{References}

Bai, Limin, 2006, "Graduate Unemployment: Dilemmas and Challenges in China's Move to Mass Higher Education," China Quarterly, 185, 128-144.

Bertrand, Marianne and Sendhil Mullainathan, "Are Emily And Greg More Employable Than Lakisha And Jamal? A Field Experiment On Labor Market Discrimination," American Economic Review, 94 (2004), 991-1013.

Buchel, Felix, 2002, "The Effects of Overeducation on Productivity in Germany-the Firms' Viewpoint," Economics of Education Review, 21, 263-275.

Buchel, Felix, Harminder Battu, 2003, "The Theory of Differential Overqualification: Does It Work?" Scottish Journal of Political Economy, 50(1), 1-16.

Borghans, Lex, Andries de Grip (eds), 2000, “The Overeducated Worker?: The Economics of Skill Utilization," Cheltenham, Edward Elgar.

Card, David. "Immigration and Inequality" American Economic Review 99(2) (May 2009): 1-21.

CEIC Data (2012) China Premium Database, available at http://www.ceicdata.com/China.html.

Frenette, Marc, 2004, "The Overqualified Canadian Graduate: the Role of the Academic Program in the Incidence, Persistence, and Economic Returns to Overqualification," Economics of Education Review, 23, 114-121.

Green, Francis, Yu Zhu, 2010, "Overqualification, Job Dissatisfaction, and Increasing Dispersion in the Returns to Graduate Education," Oxford Economic Papers, 62, 740-763.

Hartog, Joop, 2000, “Over Eduation and Earnings: Where Are We, Where Should We Go?” Economics of Education Review, 19(2), 131-147.

Hersch, Joni, 1991, "Education Match and Job Match," The Review of Economics and Statistics, 73(1), 140-144.

Hersch, Joni, 1995, “Optimal 'Mismatch' and Promotions,” Economic Inquiry, 33(4), 611-624.

Huang, Zhi-ling, Yan Lu, Xiao-Gang Fan, 2010, “An Empirical Analysis of the Impact of Overeducation on Earnings," Collected Essays on Finance and Economics, 154(6), 16-22. [in Chinese]

Kang, Ning, 2000, "Education Policy and Institutional Innovation, a Study Based on 1999 Higher Education Expansion," Journal of Higher Education (in Chinese), 2, 31-38. [in Chinese]

Kuhn, Peter J. and Kailing Shen, 2012. "Gender Discrimination in Job Ads: Theory and Evidence" Quarterly Journal of Economics, forthcoming.

Kuhn, Peter and Mikal Skuterud. "Internet Job Search and Unemployment Durations" American Economic Review 94(1) (March 2004): 218-232

Lai, De-Sheng, 2001, "Segmentation of Labor Market and Graduate Unemployment," Journal of Beijing Normal University (Social Science Edition), 4, 70-76. [in Chinese]

Lang, Kevin, Michael Manove, and William T. Dickens, 2005, "Racial Discrimination in Labor Markets with Posted Wage Offers" American Economic Review (September): 1327-1340.

Levin, Henry M., and Xu Zeyu, 2005, "Issues in the Expansion of Higher Education in the People's Republic of China," China Review, 5(1), 33-59. 
Li, Feng-Liang, Xiao-Yu Chen, and Fan Liu, 2009, "Job Search and Job Match: An Empirical Test on Higher Education Graduates,” Journal of Beijing Normal University (Social Science Edition), 5 , 126-135. [in Chinese]

McGuinness, Seamus, and Peter J. Sloane, 2011, "Labour Market Mismatching among UK Graduates: an Analysis Using REFLEX Data," Economics of Education Review, 30, 130-145.

Niederle, Muriel, and Lise Vesterlund. "Do Women Shy Away from Competition? Do Men Compete Too Much?” The Quarterly Journal of Economics 122(3), 1067- 1101. August 2007

Renes, Gusta, Geert Ridder, 1995, “Are Women Overqualified?” Labour Economics, 2(1), 3-18.

Rossheim, John "I'm Overqualified", in Resume Writing Tips: Guy's Guide to Reenergizing Your Career, monster.com, April 2012. http://career-advice.monster.com/resumes-cover-letters/resumewriting-tips/resume-dilemma-im-overqualified/article.aspx

Wang, Ting, Xiang-Quan Zeng, 2009, "Research on the Reason and Proposal of College Graduates Structural Unemployment," Education \& Economy, 1, 1-4. [in Chinese]

Wang, Xin, 2001, "A Policy Analysis of the Financing of Higher Education in China: Two Decades Reviewed," Journal of Higher Education Policy and Management, 23(2), 205-217.

Wu, Xiang-Rong, 2007, "Overeducation Phenomenon and Its Income Effects: An Empirical Analysis Based on the Current Chinese Situation," Journal of Beijing Normal University (Social Science Edition), 3, 132-136. [in Chinese]

Yao, Xian-Guo, 2009, "The Source of and Policy Recommendation for Knowledge Unemployment," Hunan Social Science, 3, 137-140. [in Chinese]

Zeng Xian-Quan, 2004, "Job Seeking of College Graduates in Employment Environment under Transition," Economic Research Journal, 6, 87-95. [in Chinese] 
Table 1: Characteristics of Xiamen and comparison cities, 2010

\begin{tabular}{|lccccc|}
\hline & Xiamen & Beijing & Shanghai & $\begin{array}{c}15 \text { sub- } \\
\text { provincial cities } \\
\text { (average) }\end{array}$ & $\begin{array}{c}\text { 268 Di-level cities } \\
\text { (average) }\end{array}$ \\
$\begin{array}{l}\text { GDP per capita in urban } \\
\text { area (RMB }{ }^{1} \text { ) }\end{array}$ & 58,337 & 75,943 & 76,074 & 64,255 & 33,360 \\
$\begin{array}{l}\text { Local Hukou population } \\
\text { (1,000s) }\end{array}$ & 1,786 & 12,518 & 14,065 & 6,870 & 3,970 \\
$\begin{array}{l}\text { Year-end resident } \\
\text { population }{ }^{2} \text { (1,000s) }\end{array}$ & 3,531 & 19,619 & 23,027 & $\mathrm{n} / \mathrm{a}$ & $\mathrm{n} / \mathrm{a}$ \\
$\begin{array}{l}\text { Local Hukou population/ } \\
\text { Resident population }\end{array}$ & $50.58 \%$ & $63.81 \%$ & $61.08 \%$ & $\mathrm{n} / \mathrm{a}$ & $\mathrm{n} / \mathrm{a}$ \\
$\begin{array}{l}\text { Year-end employed } \\
\text { population }{ }^{3} \text { (1,000s) }\end{array}$ & 1,857 & 10,770 & 7,360 & 3,018 & $\mathrm{n} / \mathrm{a}$ \\
$\begin{array}{l}\text { Employed/resident } \\
\text { population }\end{array}$ & $52.59 \%$ & $54.90 \%$ & $31.96 \%$ & $\mathrm{n} / \mathrm{a}$ & 303 \\
$\begin{array}{l}\text { Year-end employed } \\
\text { population in private } \\
\text { sector }{ }^{4} \text { (1,000s) }\end{array}$ & 903 & 4,304 & 3,431 & 1,505 & $48.44 \%$ \\
$\begin{array}{l}\text { Private sector / employed } \\
\text { population }\end{array}$ & $48.66 \%$ & $39.96 \%$ & $46.62 \%$ & $49.88 \%$ & \\
\hline
\end{tabular}

Source: GDP per capita data and year-end population for Beijing and Shanghai are from CEIC Data (2012), yearend population for Xiamen is from 2011 Yearbook of Xiamen Special Economic Zone, other data are from 2011 China City Statistical Yearbook.

Notes:

$\mathrm{n} / \mathrm{a}$ denotes statistics are not available.

1. In December 2010 one US dollar bought 6.65 RMB;

2. This refers to ChangZhuRenKou, including all individuals regardless of hukou status;

3. This refers to CongYeRenYuan, including both temporary layoffs and employed individuals;

4. This refers to ChengZhenSiYingHeGeTiCongYeRenYuan. 


\section{Table 2: Distribution of Workers' Number of Applications Sent by Education Match Categories}

\begin{tabular}{|c|c|c|c|c|c|}
\hline Workers' education: & \multicolumn{2}{|c|}{ College } & \multicolumn{2}{|c|}{ University } & \multirow[t]{2}{*}{ All Jobs } \\
\hline $\begin{array}{l}\text { Did the worker apply ONLY to jobs } \\
\text { matching his/her education level? }\end{array}$ & Yes & No & Yes & No & \\
\hline & $(1)$ & $(2)$ & (3) & $(4)$ & $(5)$ \\
\hline Number of applicants & 18,838 & 3,795 & 3,578 & 13,521 & 39,732 \\
\hline \multicolumn{6}{|l|}{ Applications sent: } \\
\hline 1 & $\begin{array}{l}11,234 \\
(9.09)\end{array}$ & $\begin{array}{l}1,036 \\
(8.11)\end{array}$ & $\begin{array}{l}2,983 \\
(8.11)\end{array}$ & $\begin{array}{c}5,649 \\
(10.75)\end{array}$ & 20,902 \\
\hline $2-4$ & $\begin{array}{c}6,333 \\
(17.78)\end{array}$ & $\begin{array}{c}1,655 \\
(19.64)\end{array}$ & $\begin{array}{c}585 \\
(16.58)\end{array}$ & $\begin{array}{l}5,708 \\
(21.60)\end{array}$ & 14,281 \\
\hline 5 or more & $\begin{array}{c}1,271 \\
(36.82)\end{array}$ & $\begin{array}{c}1,104 \\
(42.39)\end{array}$ & $\begin{array}{c}10 \\
(50.00)\end{array}$ & $\begin{array}{c}2,164 \\
(44.64) \\
\end{array}$ & 4,549 \\
\hline Average number of applications sent & 1.91 & 4.03 & 1.21 & 2.84 & 2.37 \\
\hline
\end{tabular}

Note: The numbers in parentheses are the percent of applicants that received any contacts.

\section{Table 3: Distribution of Jobs' Number of Applications Received by Education Match Categories}

\begin{tabular}{|c|c|c|c|c|c|}
\hline Job's education requirement: & \multicolumn{2}{|c|}{ College Jobs } & \multicolumn{2}{|c|}{ University Jobs } & All Jobs \\
\hline \multirow[t]{2}{*}{$\begin{array}{l}\text { Did the ad receive applications ONLY } \\
\text { from workers with exactly the } \\
\text { required education? }\end{array}$} & Yes & No & Yes & No & \\
\hline & (1) & (2) & $(3)$ & $(4)$ & (5) \\
\hline Number of jobs & 22 & 1,002 & 7 & 188 & 1,219 \\
\hline \multicolumn{6}{|l|}{ Applications received: } \\
\hline $1-40$ & $\begin{array}{c}22 \\
(54.10)\end{array}$ & $\begin{array}{c}463 \\
(19.19)\end{array}$ & $\begin{array}{c}7 \\
(26.36)\end{array}$ & $\begin{array}{c}77 \\
(17.58)\end{array}$ & 569 \\
\hline 41-100 & - & $\begin{array}{c}302 \\
(9.74)\end{array}$ & - & $\begin{array}{c}59 \\
(8.98) \\
\end{array}$ & 361 \\
\hline 101 or more & - & $\begin{array}{c}237 \\
(6.86)\end{array}$ & - & $\begin{array}{c}52 \\
(6.78)\end{array}$ & 289 \\
\hline Average number of applications received & 5.18 & 76.68 & 9.29 & 90.31 & 77.10 \\
\hline
\end{tabular}

Note: The numbers in parentheses are the percent of applications that were contacted by the employer. 
Table 4: Summary Statistics of Workers

\begin{tabular}{|l|c|c|c|c|c|}
\hline Workers' education & \multicolumn{2}{|c|}{ College } & \multicolumn{2}{|c|}{ University } & $\begin{array}{c}\text { All } \\
\text { Workers }\end{array}$ \\
\hline $\begin{array}{l}\text { Did the worker apply ONLY to jobs matching } \\
\text { his/her education level? }\end{array}$ & Yes & No & Yes & No & \\
\hline & $(1)$ & $(2)$ & $(3)$ & $(4)$ & $(5)$ \\
\hline Age & & & & & \\
\hline $18-22$ & $35 \%$ & $30 \%$ & $20 \%$ & $17 \%$ & $27 \%$ \\
\hline $23-25$ & $37 \%$ & $39 \%$ & $56 \%$ & $56 \%$ & $45 \%$ \\
\hline $26-30$ & $22 \%$ & $25 \%$ & $21 \%$ & $23 \%$ & $23 \%$ \\
\hline $31-35$ & $6 \%$ & $6 \%$ & $3 \%$ & $4 \%$ & $5 \%$ \\
\hline Work experience (years) & & & & & \\
\hline none & $25 \%$ & $20 \%$ & $42 \%$ & $37 \%$ & $30 \%$ \\
\hline 1 & $20 \%$ & $20 \%$ & $21 \%$ & $22 \%$ & $21 \%$ \\
\hline 2 & $15 \%$ & $16 \%$ & $13 \%$ & $15 \%$ & $15 \%$ \\
\hline 3 or more & $40 \%$ & $44 \%$ & $24 \%$ & $26 \%$ & $34 \%$ \\
\hline Other characteristics & & & & & \\
\hline Female & $57 \%$ & $61 \%$ & $47 \%$ & $55 \%$ & $56 \%$ \\
\hline Married & $16 \%$ & $17 \%$ & $9 \%$ & $11 \%$ & $14 \%$ \\
\hline Local Hukou & $8 \%$ & $8 \%$ & $10 \%$ & $9 \%$ & $9 \%$ \\
\hline Myopic & $32 \%$ & $34 \%$ & $51 \%$ & $47 \%$ & $39 \%$ \\
\hline New Graduate & $22 \%$ & $16 \%$ & $38 \%$ & $32 \%$ & $26 \%$ \\
\hline Number of workers & 18,838 & 3,795 & 3,578 & 13,521 & 39,732 \\
\hline Percent of workers & $47 \%$ & $10 \%$ & $9 \%$ & $34 \%$ & $100 \%$ \\
\hline
\end{tabular}


Table 5: Summary Statistics of Jobs

\begin{tabular}{|c|c|c|c|c|c|}
\hline \multirow{2}{*}{$\begin{array}{l}\text { Jobs' education requirement: } \\
\text { Did the ad receive applications } \\
\text { ONLY from workers with exactly the } \\
\text { required education? }\end{array}$} & \multicolumn{2}{|c|}{ College } & \multicolumn{2}{|c|}{ University } & \multirow[t]{2}{*}{ All jobs } \\
\hline & Yes & No & Yes & No & \\
\hline & $(1)$ & $(2)$ & (3) & $(4)$ & $(5)$ \\
\hline Require New Graduate? & $5 \%$ & $4 \%$ & $0 \%$ & $9 \%$ & $5 \%$ \\
\hline \multicolumn{6}{|l|}{ Gender requirement } \\
\hline None stated & $59 \%$ & $64 \%$ & $86 \%$ & $70 \%$ & $65 \%$ \\
\hline Male only & $9 \%$ & $9 \%$ & $0 \%$ & $12 \%$ & $9 \%$ \\
\hline Female only & $32 \%$ & $27 \%$ & $14 \%$ & $19 \%$ & $26 \%$ \\
\hline \multicolumn{6}{|l|}{ Working experience requirement } \\
\hline No & $41 \%$ & $45 \%$ & $57 \%$ & $49 \%$ & $46 \%$ \\
\hline 1 year & $14 \%$ & $21 \%$ & $14 \%$ & $24 \%$ & $21 \%$ \\
\hline 2 years & $14 \%$ & $20 \%$ & $29 \%$ & $12 \%$ & $19 \%$ \\
\hline 3 years & $32 \%$ & $14 \%$ & $0 \%$ & $15 \%$ & $14 \%$ \\
\hline \multicolumn{6}{|l|}{ Occupation } \\
\hline Sales & $18 \%$ & $15 \%$ & $0 \%$ & $13 \%$ & $14 \%$ \\
\hline international trade & $5 \%$ & $7 \%$ & $0 \%$ & $13 \%$ & $8 \%$ \\
\hline Software & $18 \%$ & $10 \%$ & $0 \%$ & $11 \%$ & $10 \%$ \\
\hline Finance & $5 \%$ & $9 \%$ & $0 \%$ & $9 \%$ & $9 \%$ \\
\hline administrative & $18 \%$ & $26 \%$ & $29 \%$ & $20 \%$ & $25 \%$ \\
\hline professional service & $18 \%$ & $7 \%$ & $43 \%$ & $12 \%$ & $8 \%$ \\
\hline manufacture & $18 \%$ & $24 \%$ & $29 \%$ & $21 \%$ & $24 \%$ \\
\hline Others & $0 \%$ & $1 \%$ & $0 \%$ & $2 \%$ & $1 \%$ \\
\hline \multicolumn{6}{|l|}{ Firm ownership } \\
\hline Foreign firms & $18 \%$ & $15 \%$ & $0 \%$ & $16 \%$ & $15 \%$ \\
\hline Domestic private firms & $73 \%$ & $70 \%$ & $71 \%$ & $70 \%$ & $70 \%$ \\
\hline Taiwan/HK/Macau firms & $9 \%$ & $9 \%$ & $14 \%$ & $8 \%$ & $9 \%$ \\
\hline Other & $0 \%$ & $6 \%$ & $14 \%$ & $6 \%$ & $6 \%$ \\
\hline \multicolumn{6}{|l|}{ \# of employees of the firm } \\
\hline $1-10$ & $18 \%$ & $10 \%$ & $29 \%$ & $9 \%$ & $10 \%$ \\
\hline $11-50$ & $27 \%$ & $34 \%$ & $43 \%$ & $35 \%$ & $34 \%$ \\
\hline $51-300$ & $45 \%$ & $39 \%$ & $0 \%$ & $30 \%$ & $38 \%$ \\
\hline$>300$ & $9 \%$ & $17 \%$ & $29 \%$ & $26 \%$ & $18 \%$ \\
\hline Number of jobs & 22 & 1,002 & 7 & 188 & 1,219 \\
\hline Percent of jobs & $2 \%$ & $82 \%$ & $1 \%$ & $15 \%$ & $100 \%$ \\
\hline
\end{tabular}


Table 6: Contact Rates of Applications, by Type

\begin{tabular}{|l|c|c|c|c|}
\hline Worker's education level: & \multicolumn{2}{|c|}{ College } & \multicolumn{2}{c|}{ University } \\
\hline Job's education requirement: & College & University & College & University \\
\hline & $(1)$ & $(2)$ & $(3)$ & $(4)$ \\
& CC & CU & UC & UU \\
\hline \# of applications & 46,578 & 4,708 & 30,366 & 12,336 \\
\hline Average \# applications per job & 45.62 & 25.04 & 30.31 & 63.92 \\
\hline Overall contact rate (\%) & 7.72 & 6.07 & 8.70 & 8.08 \\
\hline
\end{tabular}


Table 7: Regression Results for College versus University Graduates

\begin{tabular}{|c|c|c|c|c|}
\hline A: WITHOUT APPLICATION POOL CONTROLS & (1) & (2) & (3) & (4) \\
\hline $\begin{array}{l}\alpha_{1} \text { : University-educated workers' advantage over college-educated } \\
\text { workers when applying to college-level jobs }(U C-C C)\end{array}$ & $\begin{array}{c}0.0098 * * * \\
(0.002)\end{array}$ & $\begin{array}{l}0.0109 * * * \\
(0.002)\end{array}$ & $\begin{array}{l}0.0111 * * * \\
(0.002)\end{array}$ & $\begin{array}{c}0.0086 * * * \\
(0.002)\end{array}$ \\
\hline $\begin{array}{l}\alpha_{2}: \text { University-educated workers' gain from applying to education- } \\
\text { matched jobs instead of jobs they are overqualified for }(U U-U C)\end{array}$ & $\begin{array}{l}-0.0062 * * \\
(0.003)\end{array}$ & $\begin{array}{c}-0.0060 * * \\
(0.003)\end{array}$ & $\begin{array}{c}-0.0067 * * \\
(0.003)\end{array}$ & $\begin{array}{l}-0.0156 * * * \\
(0.003)\end{array}$ \\
\hline $\begin{array}{l}\alpha_{3}: \text { College-educated workers' advantage over university-educated } \\
\text { workers when applying to university-level jobs }(C U-U U)\end{array}$ & $\begin{array}{l}-0.0201 * * * \\
(0.005)\end{array}$ & $\begin{array}{l}-0.0208 * * * \\
(0.005)\end{array}$ & $\begin{array}{l}-0.0202 * * * \\
(0.005)\end{array}$ & $\begin{array}{l}-0.0132 * * * \\
(0.005)\end{array}$ \\
\hline Other Match Characteristics $\left(\right.$ Match $\left._{i j}\right)$ & & Yes & Yes & Yes \\
\hline Applicant Characteristics $\left(X_{i}\right)$ & & & Yes & Yes \\
\hline Job and Firm Characteristics $\left(Z_{j}\right)$ & & & & Yes \\
\hline$R^{2}$ & 0.001 & 0.002 & 0.002 & 0.011 \\
\hline \multicolumn{5}{|l|}{ B: WITH APPLICATION POOL CONTROLS } \\
\hline $\begin{array}{l}\alpha_{1} \text { : University-educated workers' advantage over college-educated } \\
\text { workers when applying to college-level jobs }(U C-C C)\end{array}$ & $\begin{array}{l}0.0093 * * * \\
(0.002)\end{array}$ & $\begin{array}{c}0.0100^{* * *} \\
(0.002)\end{array}$ & $\begin{array}{l}0.0102 * * * \\
(0.002)\end{array}$ & $\begin{array}{c}0.0067 * * * \\
(0.002)\end{array}$ \\
\hline $\begin{array}{l}\alpha_{2}: \text { University-educated workers' gain from applying to education- } \\
\text { matched jobs instead of jobs they are overqualified for }(U U-U C)\end{array}$ & $\begin{array}{c}-0.0000 \\
(0.003)\end{array}$ & $\begin{array}{l}0.0001 \\
(0.003)\end{array}$ & $\begin{array}{l}0.0002 \\
(0.003)\end{array}$ & $\begin{array}{c}-0.0085 * * \\
(0.004)\end{array}$ \\
\hline $\begin{array}{l}\alpha_{3}: \text { College-educated workers' advantage over university-educated } \\
\text { workers when applying to university-level jobs }(C U-U U)\end{array}$ & $\begin{array}{l}-0.0258 * * * \\
(0.005)\end{array}$ & $\begin{array}{l}-0.0264 * * * \\
(0.005)\end{array}$ & $\begin{array}{l}-0.0254 * * * \\
(0.005)\end{array}$ & $\begin{array}{l}-0.0209 * * * \\
(0.005)\end{array}$ \\
\hline Size and Mix of Applicant Pool & Yes & Yes & Yes & Yes \\
\hline Other Match Characteristics $\left(\right.$ Match $\left._{i j}\right)$ & & Yes & Yes & Yes \\
\hline Applicant Characteristics $\left(X_{i}\right)$ & & & Yes & Yes \\
\hline Job and Firm Characteristics $\left(Z_{j}\right)$ & & & & Yes \\
\hline$R^{2}$ & 0.009 & 0.010 & 0.010 & 0.020 \\
\hline
\end{tabular}

Notes: $* * * \mathrm{p}<0.01, * * \mathrm{p}<0.05, * \mathrm{p}<0.1$. All regressions are estimated as linear probability models and have 93,988 observations.

$M a t c h_{i j}$ includes dummies for whether the applicant is younger than required, older than required, less experienced than required, more experienced than required, of different gender than required, and of different "new graduate" status than required.

$X_{i}$ includes dummies for whether the applicant is female, has ever been married, has local hukou (household registration), is (literally) myopic, and is a new graduate. It also contains a set of age effects (dummies for 23-25, 26-30 and 31-35, with 18-22 as the omitted category) and experience effects ( 1 year, 2 years, and 3 years or above, with zero as the omitted category).

$Z_{j}$ includes dummies for whether the ad requests that the applicant be a new graduate, be male, or be female, as well as a set of dummies for the ad's experience requirement and dummies for 7 major occupations. $Z_{j}$ also includeds dummies for firm size (1-10, 11-50, 51-300 and 301 or more workers) and dummies for firms' ownership type.

Application pool controls are the total number of applications received for the job, plus a pair of variables that allows competing applications from mismatched workers to have different effects from matched workers' applications. 


\section{Table 8: College versus University Graduate Results with Firm Ownership Interactions}

\begin{tabular}{|c|c|c|c|c|}
\hline & $(1)$ & (2) & (3) & (4) \\
\hline A: WITHOUT APPLICATION POOL CONTROLS & Foreign firms & $\begin{array}{l}\text { Taiwan/HK/ } \\
\text { Macau firms }\end{array}$ & $\begin{array}{l}\text { Domestic } \\
\text { private firms }\end{array}$ & $\begin{array}{l}\text { SOEs and } \\
\text { other firms }\end{array}$ \\
\hline $\begin{array}{l}\alpha_{1} \text { : University-educated workers' advantage over college-educated } \\
\text { workers when applying to college-level jobs }(U C-C C)\end{array}$ & $\begin{array}{l}-0.0116^{* *} \\
(0.005)\end{array}$ & $\begin{array}{l}0.0020 \\
(0.007)\end{array}$ & $\begin{array}{l}0.0079 * * * \\
(0.003)\end{array}$ & $\begin{array}{l}0.0873 * * * \\
(0.009)\end{array}$ \\
\hline $\begin{array}{l}\alpha_{2}: \text { University-educated workers' gain from applying to education- } \\
\text { matched jobs instead of jobs they are overqualified for }(U U-U C)\end{array}$ & $\begin{array}{l}-0.0247 * * * \\
(0.007)\end{array}$ & $\begin{array}{l}0.0747 * * * \\
(0.010)\end{array}$ & $\begin{array}{l}-0.0154 * * * \\
(0.004)\end{array}$ & $\begin{array}{l}-0.1012 * * * \\
(0.011)\end{array}$ \\
\hline $\begin{array}{l}\alpha_{3}: \text { College-educated workers' advantage over university-educated } \\
\quad \text { workers when applying to university-level jobs }(C U \text {-UU })\end{array}$ & $\begin{array}{c}-0.0010 \\
(0.010)\end{array}$ & $\begin{array}{c}-0.0321 * * \\
(0.015)\end{array}$ & $\begin{array}{c}-0.0166 * * * \\
(0.006)\end{array}$ & $\begin{array}{c}-0.0309 * \\
(0.017)\end{array}$ \\
\hline$R^{2}$ & \multicolumn{4}{|c|}{0.092} \\
\hline \multicolumn{5}{|l|}{ B: WITH APPLICATION POOL CONTROLS } \\
\hline $\begin{array}{l}\alpha_{1}: \text { University-educated workers' advantage over college-educated } \\
\text { workers when applying to college-level jobs }(U C-C C)\end{array}$ & $\begin{array}{c}-0.0117 * * \\
(0.005)\end{array}$ & $\begin{array}{l}-0.0030 \\
(0.007)\end{array}$ & $\begin{array}{c}0.0063 * * \\
(0.003)\end{array}$ & $\begin{array}{c}0.0880 * * * \\
(0.009)\end{array}$ \\
\hline $\begin{array}{l}\alpha_{2}: \text { University-educated workers' gain from applying to education- } \\
\text { matched jobs instead of jobs they are overqualified for (UU-UC) }\end{array}$ & $\begin{array}{l}0.0009 \\
(0.007)\end{array}$ & $\begin{array}{l}0.0815^{* * * *} \\
(0.010)\end{array}$ & $\begin{array}{c}-0.0135 * * * \\
(0.004)\end{array}$ & $\begin{array}{l}-0.1020 * * * \\
(0.011)\end{array}$ \\
\hline $\begin{array}{l}\alpha_{3}: \text { College-educated workers' advantage over university-educated } \\
\text { workers when applying to university-level jobs }(C U-U U)\end{array}$ & $\begin{array}{c}-0.0160 \\
(0.010)\end{array}$ & $\begin{array}{l}-0.0411 * * * \\
(0.015)\end{array}$ & $\begin{array}{l}-0.0213 * * * \\
(0.006)\end{array}$ & $\begin{array}{c}-0.0332 * * \\
(0.017)\end{array}$ \\
\hline$R^{2}$ & \multicolumn{4}{|c|}{0.101} \\
\hline
\end{tabular}

Notes: $* * * \mathrm{p}<0.01, * * \mathrm{p}<0.05, * \mathrm{p}<0.1$. All coefficients in Panel A are from a single regression, specified according to column 4 in panel A of Table 7. All regressions are estimated as linear probability models and have 93,988 observations. The only difference is that the education-matching coefficients are interacted with firm ownership type. Panel B adds controls for the size and mix of the applicant pool to this regression. 


\section{Table 9: Regression Results for Technical School versus College Graduates}

\begin{tabular}{|c|c|c|c|c|}
\hline A: WITHOUT APPLICATION POOL CONTROLS & (1) & (2) & (3) & (4) \\
\hline $\begin{array}{l}\alpha_{1}: \text { College-educated workers' advantage over tech school-educated } \\
\text { workers when applying to tech school-level jobs }(C T-T T)\end{array}$ & $\begin{array}{l}-0.0177 * * * \\
(0.003)\end{array}$ & $\begin{array}{l}-0.0179 * * * \\
(0.003)\end{array}$ & $\begin{array}{l}-0.0161 * * * \\
(0.004)\end{array}$ & $\begin{array}{l}-0.0166 * * * \\
(0.004)\end{array}$ \\
\hline $\begin{array}{l}\alpha_{2}: \text { College-educated workers' gain from applying to education- } \\
\text { matched jobs instead of jobs they are overqualified for }(C C-C T)\end{array}$ & $\begin{array}{l}0.0132 * * * \\
(0.002)\end{array}$ & $\begin{array}{l}0.0136 * * * \\
(0.002)\end{array}$ & $\begin{array}{l}0.0136^{* * *} \\
(0.002)\end{array}$ & $\begin{array}{l}0.0153 * * * \\
(0.003)\end{array}$ \\
\hline $\begin{array}{l}\alpha_{3}: \text { Tech school-educated workers' advantage over college-educated } \\
\text { workers when applying to college-level jobs }(T C-C C)\end{array}$ & $\begin{array}{l}-0.0005 \\
(0.004)\end{array}$ & $\begin{array}{l}-0.0004 \\
(0.004)\end{array}$ & $\begin{array}{l}-0.0013 \\
(0.004)\end{array}$ & $\begin{array}{l}-0.0020 \\
(0.004)\end{array}$ \\
\hline Other Match Characteristics $\left(\right.$ Match $\left._{i j}\right)$ & & Yes & Yes & Yes \\
\hline Applicant Characteristics $\left(X_{i}\right)$ & & & Yes & Yes \\
\hline Job and Firm Characteristics $\left(Z_{j}\right)$ & & & & Yes \\
\hline$R^{2}$ & 0.001 & 0.001 & 0.003 & 0.008 \\
\hline \multicolumn{5}{|l|}{ B: WITH APPLICATION POOL CONTROLS } \\
\hline $\begin{array}{l}\alpha_{1}: \text { College-educated workers' advantage over tech school-educated } \\
\text { workers when applying to tech school-level jobs }(C T-T T)\end{array}$ & $\begin{array}{l}-0.0158 * * * \\
(0.003)\end{array}$ & $\begin{array}{l}-0.0165 * * * \\
(0.003)\end{array}$ & $\begin{array}{l}-0.0143 * * * \\
(0.004)\end{array}$ & $\begin{array}{l}-0.0142 * * * \\
(0.004)\end{array}$ \\
\hline $\begin{array}{l}\alpha_{2}: \text { College-educated workers' gain from applying to education- } \\
\text { matched jobs instead of jobs they are overqualified for }(C C-C T)\end{array}$ & $\begin{array}{l}0.0292 * * * \\
(0.003)\end{array}$ & $\begin{array}{l}0.0301 * * * \\
(0.003)\end{array}$ & $\begin{array}{l}0.0301 * * * \\
(0.003)\end{array}$ & $\begin{array}{l}0.0292 * * * \\
(0.003)\end{array}$ \\
\hline $\begin{array}{l}\alpha_{3} \text { : Tech school-educated workers' advantage over college-educated } \\
\text { workers when applying to college-level jobs }(T C-C C)\end{array}$ & $\begin{array}{l}0.0002 \\
(0.004)\end{array}$ & $\begin{array}{l}0.0013 \\
(0.004)\end{array}$ & $\begin{array}{l}-0.0007 \\
(0.004)\end{array}$ & $\begin{array}{l}-0.0016 \\
(0.004)\end{array}$ \\
\hline Size and Mix of Applicant Pool & Yes & Yes & Yes & Yes \\
\hline Other Match Characteristics $\left(\right.$ Match $\left._{i j}\right)$ & & Yes & Yes & Yes \\
\hline Applicant Characteristics $\left(X_{i}\right)$ & & & Yes & Yes \\
\hline Job and Firm Characteristics $\left(Z_{j}\right)$ & & & & Yes \\
\hline$R^{2}$ & 0.017 & 0.019 & 0.019 & 0.024 \\
\hline
\end{tabular}

Notes: $* * * \mathrm{p}<0.01, * * \mathrm{p}<0.05, * \mathrm{p}<0.1$. All regressions are estimated as linear probability models and have 75,393 observations. See Table 7 for detailed regression specifications. 
Table 10: Technical School versus College Graduates Results with Firm Ownership Interactions

\begin{tabular}{|c|c|c|c|c|}
\hline & (1) & (2) & (3) & (4) \\
\hline A: WITHOUT APPLICATION POOL CONTROLS & Foreign firms & $\begin{array}{l}\text { Taiwan/HK/ } \\
\text { Macau firms }\end{array}$ & $\begin{array}{l}\text { Domestic } \\
\text { private firms }\end{array}$ & $\begin{array}{l}\text { SOEs and } \\
\text { other firms }\end{array}$ \\
\hline $\begin{aligned} \alpha_{1}: & \text { College-educated workers' advantage over tech school-educated } \\
& \text { workers when applying to tech school-level jobs }(C T-T T)\end{aligned}$ & $\begin{array}{l}-0.0174 * \\
(0.010)\end{array}$ & $\begin{array}{l}-0.0486 * * * \\
(0.012)\end{array}$ & $\begin{array}{l}-0.0131 * * * \\
(0.004)\end{array}$ & $\begin{array}{l}-0.0112 \\
(0.015)\end{array}$ \\
\hline $\begin{array}{l}\alpha_{2}: \text { College-educated workers' gain from applying to education- } \\
\text { matched jobs instead of jobs they are overqualified for }(C C-C T)\end{array}$ & $\begin{array}{l}0.0483 * * * \\
(0.007)\end{array}$ & $\begin{array}{l}0.0477 * * * \\
(0.009)\end{array}$ & $\begin{array}{l}0.0053^{*} \\
(0.003)\end{array}$ & $\begin{array}{l}0.0248 * * \\
(0.011)\end{array}$ \\
\hline $\begin{array}{l}\alpha_{3}: \text { Tech school-educated workers' advantage over college-educated } \\
\text { workers when applying to college-level jobs }(T C-C C)\end{array}$ & $\begin{array}{l}-0.0132 \\
(0.011)\end{array}$ & $\begin{array}{l}0.0285^{* *} \\
(0.012)\end{array}$ & $\begin{array}{l}-0.0036 \\
(0.005)\end{array}$ & $\begin{array}{l}-0.0264 \\
(0.017)\end{array}$ \\
\hline$R^{2}$ & \multicolumn{4}{|c|}{0.095} \\
\hline \multicolumn{5}{|l|}{ B: WITH APPLICATION POOL CONTROLS } \\
\hline $\begin{aligned} \alpha_{1}: & \text { College-educated workers' advantage over tech school-educated } \\
& \text { workers when applying to tech school-level jobs }(C T-T T)\end{aligned}$ & $\begin{array}{l}-0.0063 \\
(0.010)\end{array}$ & $\begin{array}{l}-0.0479 * * * \\
(0.011)\end{array}$ & $\begin{array}{l}-0.0121 * * * \\
(0.004)\end{array}$ & $\begin{array}{l}-0.0092 \\
(0.015)\end{array}$ \\
\hline $\begin{aligned} \alpha_{2}: & \text { College-educated workers' gain from applying to education- } \\
& \text { matched jobs instead of jobs they are overqualified for }(C C-C T)\end{aligned}$ & $\begin{array}{l}0.0395 * * * \\
(0.008)\end{array}$ & $\begin{array}{l}0.0734 * * * \\
(0.009)\end{array}$ & $\begin{array}{l}0.0201 * * * \\
(0.004)\end{array}$ & $\begin{array}{l}0.0506 * * * \\
(0.011)\end{array}$ \\
\hline $\begin{array}{l}\alpha_{3}: \text { Tech school-educated workers' advantage over college-educated } \\
\text { workers when applying to college-level jobs }(T C-C C)\end{array}$ & $\begin{array}{l}-0.0183 \\
(0.011)\end{array}$ & $\begin{array}{l}0.0249 * * \\
(0.012)\end{array}$ & $\begin{array}{l}-0.0016 \\
(0.005)\end{array}$ & $\begin{array}{l}-0.0252 \\
(0.017)\end{array}$ \\
\hline$R^{2}$ & \multicolumn{4}{|c|}{0.110} \\
\hline
\end{tabular}

Notes: $* * * \mathrm{p}<0.01, * * \mathrm{p}<0.05, * \mathrm{p}<0.1$. All coefficients in Panel A are from a single regression, specified according to column 4 in panel A of Table 9. All regressions are estimated as linear probability models and have 75,393 observations. The only difference is that the education-matching coefficients are interacted with firm ownership type. Panel B adds controls for the size and mix of the applicant pool to this regression. 
Figure 1: Number of University and College Students Graduated and Admitted, 1949-2010

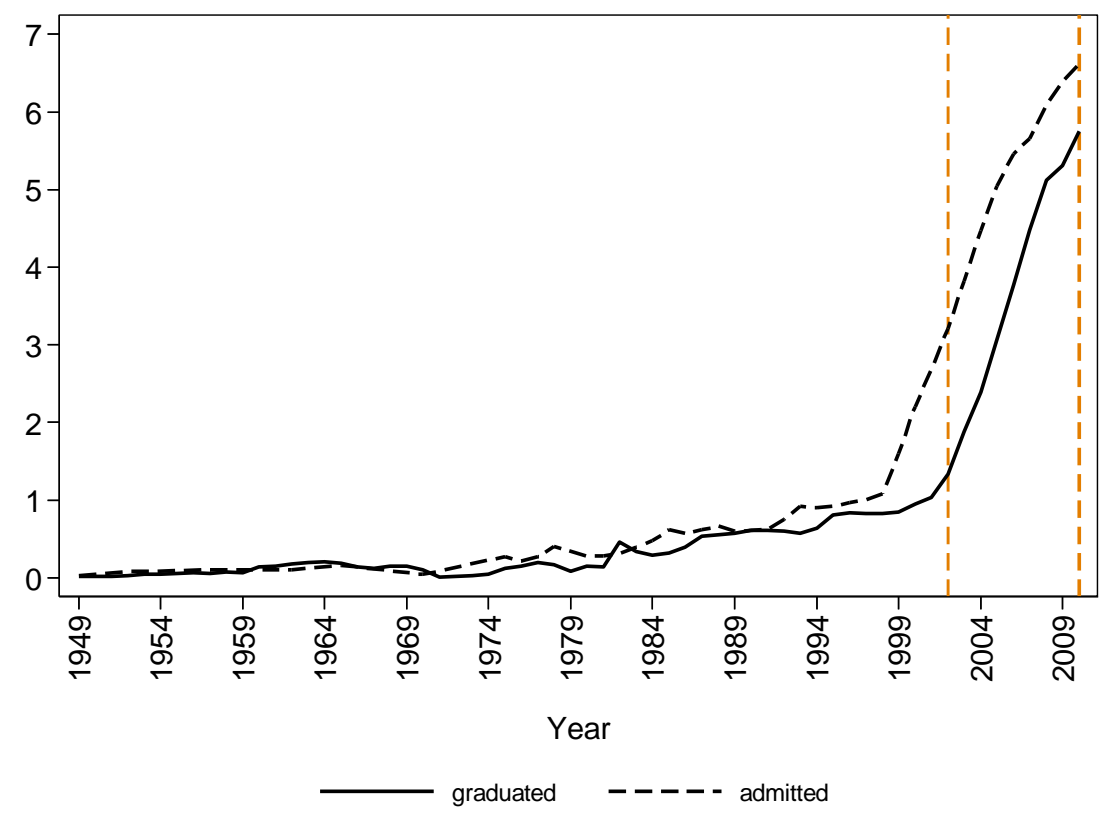

Source: China Education Yearbook, China Education Statistical Yearbook and China Statistical Yearbook of various years.

Figure 2: Number of Students Graduated from Universities, Colleges and Technical Schools, 19862010

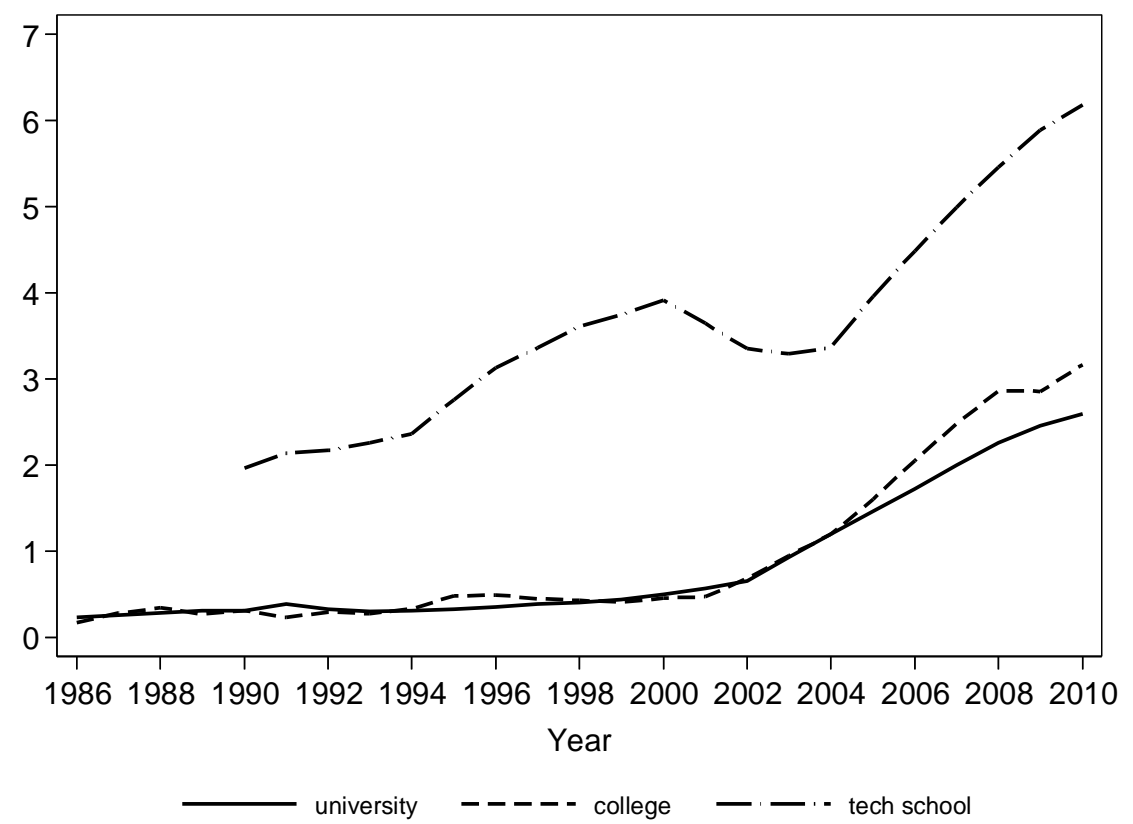

Note: The numbers of technical school graduates correspond to the total of graduates from "ZhongDengZhuanYeXueXiao (Regular Specialized Secondary Schools)", "JiGongXueXiao (Technical Schools)", and "ZhiYeZhongXue (Secondary Vocational Schools)". Source: China Education Yearbook, China Education Statistical Yearbook and China Statistical Yearbook of various years. 


\section{Figure 3: Number of jobseekers and vacancies by education group, China}

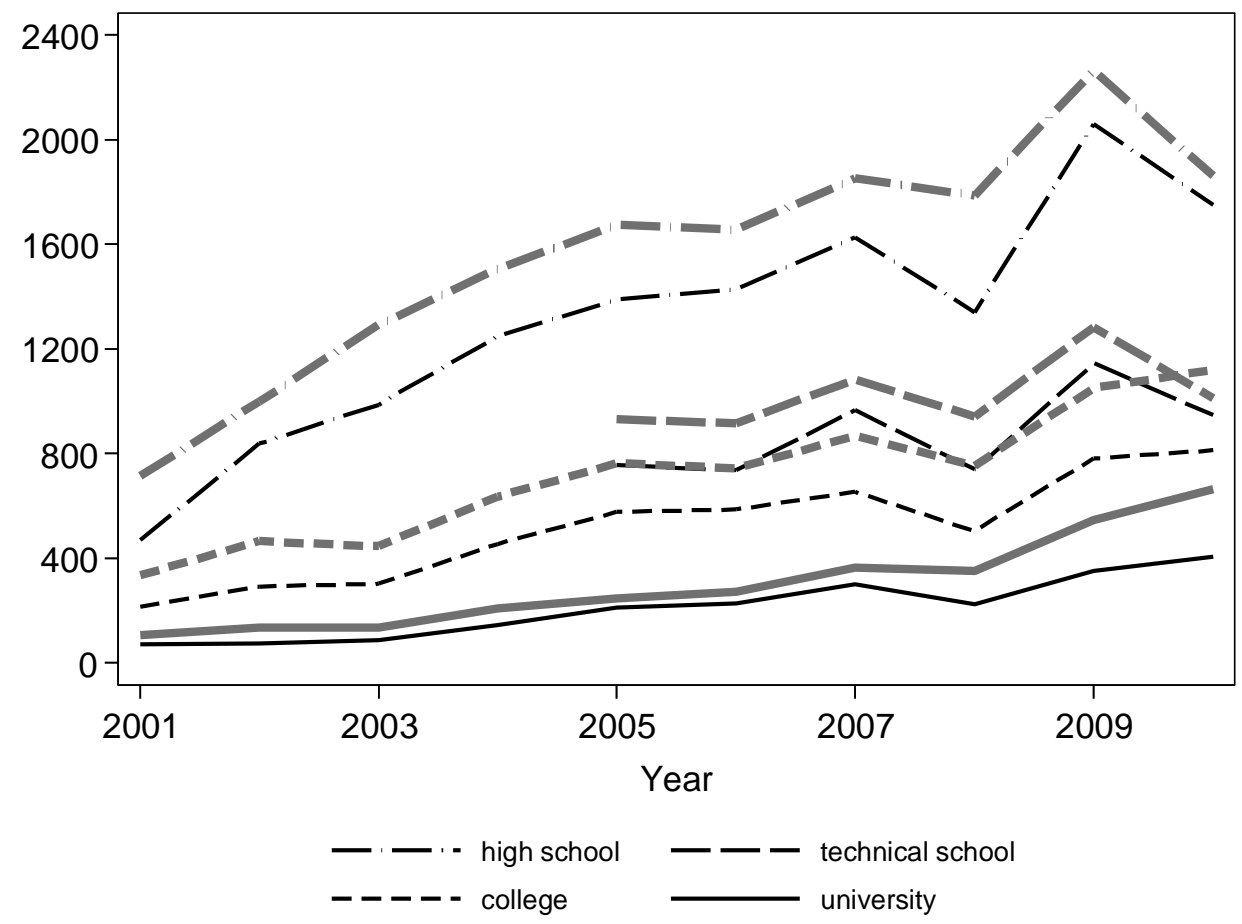

Note: The lighter and thicker lines are for jobseekers at corresponding education levels, and the darker and thinner lines are for vacancies at corresponding education levels.

Source: CEIC China Economic Database. High school statistics include technical school. Separate statistics for technical school, which became available in 2005 are also reported. 